\section{Regards sur l'économie allemande}

Bulletin économique du CIRAC

$83 \mid 2007$

Varia

\title{
Ethique des affaires
}

BESCHORNER Thomas, SCHMIDT Matthias (eds), Unternehmerische Verantwortung in Zeiten kulturellen Wandels / WIELAND Josef (ed), Dezentralisierung und weltweite Kooperationen. Die moralische Herausforderung der Unternehmen

\section{(2)enEdition}

\section{Journals}

Édition électronique

URL : http://journals.openedition.org/rea/428

DOI : $10.4000 /$ rea. 428

ISBN : 978-2-8218-0862-1

ISSN : 1965-0787

Éditeur

CIRAC

Édition imprimée

Date de publication : 1 octobre 2007

ISSN : 1156-8992

Référence électronique

"Ethique des affaires », Regards sur l'économie allemande [En ligne], 83 | octobre 2007, document 3 ,

mis en ligne le 22 avril 2008, consulté le 22 septembre 2020. URL : http://journals.openedition.org/rea/ 428 ; DOI : https://doi.org/10.4000/rea.428

Ce document a été généré automatiquement le 22 septembre 2020.

(c) CIRAC 


\section{Ethique des affaires}

BESCHORNER Thomas, SCHMIDT Matthias (eds), Unternehmerische Verantwortung in Zeiten kulturellen Wandels / WIELAND Josef (ed), Dezentralisierung und weltweite Kooperationen. Die moralische Herausforderung der Unternehmen

\section{RÉFÉRENCE}

BESCHORNER Thomas, SCHMIDT Matthias (eds), Unternehmerische Verantwortung in Zeiten kulturellen Wandels, Coll. Schriftenreihe für Wirtschafts- und Unternehmensethik, vol. 15, Rainer Hampp Verlag, Munich, 2006, 272 p. WIELAND Josef (ed), Dezentralisierung und weltweite Kooperationen. Die moralische Herausforderung der Unternehmen, Metropolis Verlag, Marburg, 2000, $167 \mathrm{p}$.

1 Voilà deux ouvrages qui montrent comment vit concrètement le concept de libéralisme organisé qui caractérise l'organisation de la société allemande. Il repose sur une éthique très forte, d'origine certes protestante, mais largement partagée par l'ensemble des entreprises : elle respecte foncièrement les libertés (dont le libéralisme du marché), mais celles-ci ne peuvent s'exercer que si l'action responsable des acteurs (les patrons, en l'occurrence), leur donne un cadre de référence (construit sur des valeurs). Or la globalisation des activités privilégie dans un premier temps le libéralisme, qu'il s'agit désormais d'encadrer par une éthique. C'est là le défi que thématisent ces deux ouvrages, réalisés conjointement par les milieux économiques et universitaires. (ib) 